\title{
Familism Scale: Confirmatory Factor Analysis in a Sample of Caregivers of Older Adults
}

\author{
Deusivania Vieira da Silva Falcão ${ }^{1,2}$ (D) https://orcid.org/0000-0001-6839-4606 \\ Daniel Paulson ${ }^{2}$ (D) https://orcid.org/0000-0002-4299-2437 \\ Manuel Herrera Legon ${ }^{2}$ (D) https://orcid.org/0000-0002-1071-7852 \\ Carolina Irurita-Ballesteros ${ }^{2}$ (D) https://orcid.org/0000-0003-4826-1931
}

\begin{abstract}
The objective of this study was to translate and confirm the factor structure of the Familism Scale in the Brazilian Portuguese version. The sample included 716 Brazilian caregivers providing care to their own aging parents with Alzheimer's Disease. The measures included the Familism Scale, the Filial Obligation Scale, the Life Satisfaction scale and the Center for Epidemiological Studies-Depression scale (CES-D). The questionnaire was individually filled online with use of the survey software package Qualtrics. Confirmatory Factor Analysis was used to examine the factor structure. The modified model demonstrated adequate fit $(\mathrm{RMSEA}=.063, \mathrm{CFI}=.912)$. The hypotheses concerning convergence and divergence of validity from relevant variables were corroborated. These results support the use of the modified Familism Scale including twelve items and two factors with acceptable psychometric properties in a sample of Brazilian caregivers with Alzheimer's Disease.
\end{abstract}

Keywords: family, caregivers, aged, Alzheimer's disease

\section{Escala de Familismo: Análise Fatorial Confirmatória numa Amostra de Cuidadores de Idosos}

\begin{abstract}
Resumo: O objetivo deste estudo foi traduzir e confirmar a estrutura fatorial da Escala de Familismo na versão da língua portuguesa brasileira. A amostra incluiu 716 cuidadores brasileiros que cuidavam de seus próprios pais idosos com doença de Alzheimer. As medidas incluíram a Escala de Familismo, Escala de Obrigação Filial, Escala de Satisfação com a Vida e a Center for Epidemiologic StudiesDepression (CES-D). O questionário foi preenchido on-line e respondido individualmente usando a ferramenta de software de pesquisa da Qualtrics. A análise fatorial confirmatória (AFC) foi utilizada para examinar a estrutura fatorial. Um modelo modificado demonstrou um ajuste adequado $(\mathrm{RMSEA}=.063, \mathrm{CFI}=.912$ ). Hipóteses envolvendo convergência e divergência de validade de variáveis relevantes foram suportadas. Estes resultados apoiam o uso da Escala de Familismo modificada em doze itens e três fatores, que tem propriedades psicométricas aceitáveis em uma amostra de cuidadores brasileiros de pessoas com doença de Alzheimer.
\end{abstract}

Palavras-chave: família, cuidadores, idosos, doença de Alzheimer

\section{Escala de Familismo: Análisis Factorial Confirmatorio en una Muestra de Cuidadores de Ancianos}

\begin{abstract}
Resumen: El objetivo del presente estudio fue traducir y confirmar la estructura factorial de la Escala de Familismo a la versión del portugués brasileño. La muestra incluyó a 716 cuidadores brasileños que cuidaron de sus propios padres ancianos con enfermedad de Alzheimer. Las medidas incluyeron la Escala de Familismo, la Escala de Obligación Filial, la Escala de Satisfacción con la Vida y el Center for Epidemiologic Studies-Depression (CES-D). El cuestionario se rellenó en línea, de manera individual, utilizando la herramienta de software de encuestas en línea Qualtrics. El análisis factorial confirmatorio (AFC) se utilizó para examinar la estructura factorial. Un modelo modificado demostró un adecuado ajuste (RMSEA =.063, CFI =.912). Se sostuvieron las hipótesis que implican la convergencia y la divergencia de validez de las variables relevantes. Estos resultados respaldan el uso de la Escala de Familismo modificada de doce ítems y tres factores, que tiene propiedades psicométricas aceptables en una muestra de cuidadores brasileños de personas con enfermedad de Alzheimer.
\end{abstract}

Palabras clave: familia, cuidadores, adultos mayores, enfermedad de Alzheimer

${ }^{1}$ Universidade de São Paulo, São Paulo-SP, Brazil

${ }^{2}$ University of Central Florida, Orlando-FL, United States

Correspondence address: Deusivania Vieira da Silva Falcão. Universidade de São Paulo. Gerontologia. Rua Arlindo Béttio, 1000 - Jardim Keralux, São Paulo-SP, Brazil. CEP 03.828-000. Email: deusivania@usp.br
The family unit is a central element in Hispanic and Latin American cultures. The term familism (also referred to as familismo or familialism) highlights the significance of the cultural value of family for Latin American populations (Bostean \& Gillespie, 2018). Among Brazil's older adults, 
$30.1 \%$ reported difficulties in conducting one or more activities of daily living, and among those with functional limitations, $81.2 \%(n=5,978)$ reported receiving or needing help to perform at least one activity of daily living (Lima-Costa, Peixoto, Malta, Szwarcwald, \& Mambrini, 2017). In cultures worldwide, informal caregiving is an increasingly recognized matter of social concern, and considerable attention has been devoted to understanding the psychosocial determinants of caregiving behaviors between family members. Family-centered constructs such as familism and filial obligation have received attention in the gerontological literature (Casado, Lee, Hong, \& Hong, 2015; McCleary \& Blain, 2013; Song, Yan, \& Sörensen, 2017); however, the authors are unaware of quantitative studies on familism and dementia caregiving in Brazil.

There is no universal definition for familism; however, past work (Hernández \& Bámaca-Colbert, 2016) has characterized familism as a multidimensional construct constituted by at least the following dimensions: demographic (e.g., family size), structural (e.g., cohesion of extended families networks), behavioral (e.g., contact with family and support), and normative or attitudinal domains (e.g., beliefs about family). Familism conceptualizations are similar in that they all reflect core values such as strong family identification and attachment of people with their families, and solid feelings of family obligation, familial interconnectedness, loyalty, reciprocity, and mutual support and solidarity among the members of the nuclear and extended family (Mendez-Luck, Applewhite, Lara, \& Toyokawa, 2016; Sabogal, Marín, Otero-Sabogal, Marín, \& Perez-Stable, 1987; Triandis, Marín, Betancourt, Lisansky, \& Chang, 1982). Familism promotes cohesiveness and obedience within the family, which relates to outcomes that are considered desirable in collectivist cultures, such as emotional support and preservation of in-home care (Killoren, Alfaro, \& Kline, 2016).

Cultural values such as familism, beliefs and positive views of the caregiving role are important variables that may influence the decision of who will provide care to dementia patients, the setting in which care will be provided, and to delay institutionalizing a loved one with dementia. In some cultures, especially in Latin American, Asian, and Mediterranean countries (Vellone, Piras, Venturini, Alvaro, \& Cohen, 2012), caring for the elderly has traditionally been family-based compared to North-American and other European countries where institutionalization is more common. The reason is likely the widespread Latin-American belief that the elderly should be cared for by family (ArévaloFlechas, Acton, Escamilla, Bonner, \& Lewis, 2014; Moreno et al., 2015). Given this emphasis on loyalty, caregivers in Latino cultures tend to sacrifice their own needs in order to provide care for family members (Gelman, 2014).

Familism is also conceptually related to filial obligation. Both variables reflect a cultural standard of responsible social behavior toward one's own family or kin. For both familism and filial obligation, this standard is based on needs, friendship, and an implicit promise of reciprocity that is derived from being in a parent-child relationship. Theory and research related to both filial obligation and familism suggest that a family member with high scores on either dimension may be more likely to assume responsibility for the care of an aging family member with dementia (Pinquart, Sörensen, \& Song, 2018). From this perspective, adult children are expected to "pay back" the love and support provided to them while growing up (Lee \& Szinovacz, 2016; Miyawaki, 2016; Stuifbergen \& Van Delden, 2011). Stein et al. (2014) concluded that Latino families may express familism via messages of respect for adults within the family. Children internalize values and beliefs to which they are exposed, which in turn influence their own beliefs and decision-making as adults. Among adolescents, familism has been positively associated with the perception of parents serving as legitimate sources of guidance, authority, cohesion, and positive parent-child communication/relationship.

In Hispanic and Latin-American cultures, familism is considered a crucial protective factor for physical and psychological well-being, especially during periods of crisis and psychological distress (Campos, Ullman, Aguilera, \& Schetter, 2014; Valdivieso-Mora, Peet, Garnier-Villarreal, Salazar-Villanea, \& Johnson, 2016). Familism is associated with frequency of self-care behavior, treatment adherence, better disease management, practice of physical exercise and academic performance (Corona, Campos, \& Chen, 2017; Halgunseth et al., 2017; Perez \& Cruess, 2014). In addition, familism was positively associated with mental health and general life satisfaction (Fuller-Iglesias \& Antonucci, 2016; Marsiglia, Booth, Baldwin, \& Ayers, 2013; Ojeda \& PiñaWatson, 2013).

However, other research examining the influence of familism on psychological well-being has produced inconsistent results. For instance, familism has been described as both a risk factor (Valdivieso-Mora et al., 2016) and a protective factor (Corona et al., 2017) for depression. Others have found that familism confers a motivation for providing care, acceptance of the caregiving role, and perception of positive caregiving experiences (Mendez-Luck et al., 2016). Familism score is correlated with endorsement of the perspective that family support is beneficial for overcoming depression (Keeler, Siegel, \& Alvaro, 2014). On the other hand, among Latin-American and Hispanic caregivers living in the United States, familism is positively associated with both depression and the perception of level of control by family members (Villalobos \& Bridges, 2015).

As with other variables reflecting cultural standards of responsible behavior toward family, such as filial obligation or filial piety, adopted cultural values influence the experience of dementia caregivers. Sabogal et al. (1987) examined the effects of acculturation on attitudinal familism in a sample of 452 Hispanic adults with different countries of origin and 227 whites non-Hispanics. The familism scale used in this study was composed of 14 items adapted from the scales developed by Bardis (1959) and by Triandis et al. (1982). Factor analysis indicated the presence of three factors (Familial Obligations, Perceived Support from the Family, and Family as Referents) that accounted for $48.4 \%$ of the variance in the 14 items. The Familial Obligation dimension assesses one's perceived obligation to provide material and emotional support 
Falcão, D. V. S., Paulson, D., Legon, M. H., \& Irurita-Ballesteros, C. (2019). Familism Scale in a Sample of Caregivers.

to the members of the family. The Perceived Support from the Family dimension assesses the perception of family members as reliable providers of help and support for problem solving. The Family as Referents factor was designed to assess the degree to which family serve as behavioral and attitudinal referents.

Previous Brazilian qualitative research (Santos, de Sousa, Ganem, Silva, \& Dourado, 2013) suggested that familism may be one cultural determinant of caregiving behavior, though no quantitative research has elaborated further on this. The lack of a well-normed Portuguese-language measure of familism may be one reason for this. Considering the paucity of instruments for investigating familism in Brazil and the importance of understanding how such strategies aid the process of the child's adaptation to the parent's Alzheimer's disease (AD) process, the aim of this study was (a) to translate the Familism Scale (Sabogal et al., 1987) into Portuguese for use with a Brazilian sample, (b) examine the factor structure of the translated measure, and (c) establish preliminary evidence for the convergent and divergent validity of the translated measure.

\section{Method}

\section{Participants}

The participants were a non-probabilistic sample of 716 adult children caregivers who took care of their aging parents suffering from $\mathrm{AD}$ at home. Inclusion criteria for the caregivers were: (a) must be a Brazilian citizen; (b) must be the one responsible (primary or secondary) for caring for the aging father or mother with diagnosis of $\mathrm{AD}$ and related disorders; (c) must have been caring for either the mother or father with diagnosis of $\mathrm{AD}$ and related disorders for 6 months; (d) must agree to participate in the research. Inclusion criteria for the mother or father: (a) must be 60 or older; (b) must have been diagnosed with $\mathrm{AD}$ and related disorders; and (c) communitydwelling older people. In total, 1,176 research participants consented to participate in this study. After applying the aforementioned criteria, the final sample included 716 individuals. Cases where participants gave identical answers for all questions (a common and easily identified method of invalid responding) were also excluded from the analysis. It was not necessary to inform the respondents of this decision.

\section{Instruments}

Demographic and socioeconomic information of caregivers and seniors: The assessed demographic variables included gender (male or female), marital status (single, married, divorced, separated, widowed), age, level of education (middle school, high school, associate's degree, Bachelor's degree, graduate degree), maternal or paternal relationship with care receiver, perception of what stage the disease is in: initial, moderate, advanced (clinical descriptions were provided to characterize each response option), who is the primary caregiver of the senior with $\mathrm{AD}$, approximate length of time the aging person has been cared, position of birth among siblings, living arrangements, and in which region of Brazil they live.

Familism: The Familism Scale (FS) used in this research was originally developed by Sabogal et al. (1987), who used items from the other researchers (Bardis, 1959; Triandis et al., 1982) Scales. The items are answered in a 5-point Likerttype scale, ranging from 1 (strongly disagree) to 5 (strongly agree). Sabogal et al. (1987) identified three factors: (1) family obligation; (2) perceived family support; and the (3) family as a reference. Cronbach's alphas for the three respective dimensions of the original English language scale were .76, .70 and .64, respectively (Sabogal et al., 1987).

Filial Obligation: The Obligation Scale (Cicirelli, 1992) is a scale of seven items that objectively measures the overall feelings of filial obligation. The respondent is asked to indicate, on a 5-point Likert scale (1 being "strongly disagree" and 5 being "strongly agree"), how important each statement is towards caring for parents. This measure includes questions such as "Is it the child's duty to help?" The scores may vary from 7 to 30; a higher score represents a stronger sense of obligation to caring for one's parents. This scale was translated to Brazilian Portuguese and will be subjected to validation in another study. This translated measure had adequate internal consistency in this sample (Cronbach's $\alpha=.77$ ).

Life Satisfaction: this was measured on a scale of overall satisfaction with life (Diener, Emmons, Larsen, \& Griffin, 1985). The Satisfaction with Life Scale is used in the international literature to measure the overall level of life satisfaction of respondents. It is one-dimensional and has 5 items using a 7-point Likert scale. This study was reduced to a 5-point scale (ranging from strongly agree to strongly disagree). It was translated, adapted and validated in Brazil by Gouveia, Milfont, Fonseca, and Coelho (2009). Internal consistency in the gathered data was high (Cronbach's $\alpha=.87$ ).

Depression: The Center for Epidemiologic Studies Depression Scale (CES-D) (Radloff, 1977) was used to measure the frequency with which caregivers experience each one of the 20 indicators of depression. The original study involving this instrument (Radloff, 1977) had a structure of four oblique factors: positive affection, depression, reduced somatic/activity aspects, and interpersonal issues. The participants are asked to respond "yes" or "no" to each item on the scale, based on their experiences during the previous week. The scoring varies from 0 to 56; higher number of symptoms of depression. Internal consistency in this data was high (Cronbach's $\alpha=.84$ ).

\section{Procedure}

Developing the Brazilian Portuguese version of the Familism Scale. The translation of the original Familism scale to the Brazilian Portuguese version included several steps, based on the International Commission guidelines (International Test Commission [ITC], 2010) and in accordance with the stages of the instruments' adaptation proposed by Borsa, Damásio, and Bandeira (2012). Initially, two independent multilingual translators that had previous knowledge of familism translated the questionnaire from English into Brazilian Portuguese. 
The first translator is a psychogerontologist whose academic research focuses primarily on family relationships within the context of aging and dementia caregiving. The second translator is a student in the American Psychological Association accredited a Doctorate degree in Clinical Psychology at the University of Central Florida. He is experienced in the administration of evidence-based interventions for dementia caregivers. A synthesis of the two versions was then conducted. The synthesized version was assessed through psychometric evaluation by a target group and by a group of two experts who belonged to the psychological field and had specific knowledge on the familism construct. After minor revisions, the final version was back-translated from Brazilian Portuguese to English by a third independent bilingual translator and was considered both grammatically and semantically equivalent. The third translator is a multilingual native of South America who lives in United States and completed her $\mathrm{PhD}$ in Psychology in Brazil. Both versions were compared with each other by an English native speaker.

Data collection. The questionnaire was available online with use of the Qualtrics survey software tool (Qualtrics, 2013). Participants received an invitation via email and social networks to participate in the study, directing them to the questionnaire. Emails were also sent to some academic researchers and support group coordinators from family caregiving institutions such as Abraz (Brazilian Alzheimer's Association). To show appreciation for participating, after they have finished completing the questionnaire, the adult caregiver's children had access to a video class on family relationships with elderly Alzheimer's sufferers.

Data analysis. Statistical analysis was performed using the SPSS (version 25.0) software package for Windows. For data analysis purposes, there were no missing values. Missing data was minimized by requiring that all questions in the survey be answered before proceeding, and questionnaires with incomplete items were excluded.

Confirmatory factor analysis (CFA) of the familism scale was completed using the MPlus (version 7.4) software package. The following adjustment indicators were considered (Tabachnick \& Fidell, 2013): chi-square ( $\chi^{2}$ ideal low values); Goodness-of-Fit Index - GFI (values ranging from 0 to 1 , where indexes close to or greater than 0.90 represent an appropriate fit) (Hooper, Coughlan, \& Mullen, 2008). Good model fit was indicated by Root Mean Square Error of Approximation (RMSEA) with values at or below .08, Standardized Root Mean Squared Residual (SRMR) with values less than .08, and Comparative Fit Index (CFI) values above .90 , which is considered evidence of an acceptable model fit (Hooper et al., 2008; Hu \& Bentler, 1999).

In this study, MLR (Robust Maximum Likelihood) estimator was employed in light of non-normal item-level data. The described models were estimated based on a covariance matrix using MLR. This estimator is robust to moderate violations of normality when used with CFA models (Li, 2016). When applied like this, MLR has the advantage that parameter estimates are obtained using the asymptotically unbiased ML estimator, but standard errors and chi-square test statistics are statistically corrected to improve the robustness of ML against departure from normality (in the forms of kurtosis, skewness, or both) (Kaplan, 2008; Muthén \& Muthén, 2012).

\section{Ethical Considerations}

This study was approved by the Institutional Review Board at University of Central Florida (UCF, USA) and by the Ethics Committee of School of Arts, Science and Humanities (EACH) at the University of São Paulo (USP, Brazil), under No. CEP 58795716.3.0000.5390. The caregivers were informed of the objectives of the study and were guaranteed anonymity and confidentiality.

\section{Results}

\section{Demographic and socioeconomic information of caregivers and the elderly}

The participants were a sample of 716 adult children caregivers ( $92.5 \%$ women; with mean age of 48.7 years) who took care of their aging parents suffering from Alzheimer's disease at home. The sample is described in Table 1.

Table 1

Descriptive statistics and demographic characteristics of caregivers

\begin{tabular}{lcc}
\hline & Mean $(S D)$ & Range \\
\hline Age (years) & $48.7(9.7)$ & 69 \\
CES-D & $44.3(11.2)$ & 57 \\
Life satisfaction & $14.7(4.5)$ & 20 \\
Filial obligation & $30.1(4.1)$ & $\%$ \\
& Group & 92.5 \\
Gender (Female) & & \\
Parent with Alzheimer disease & & \\
& Mother & 73.6 \\
& Father & 24.7 \\
& Both (mother and father) & 1.7 \\
\hline
\end{tabular}


Falcão, D. V. S., Paulson, D., Legon, M. H., \& Irurita-Ballesteros, C. (2019). Familism Scale in a Sample of Caregivers.

\begin{tabular}{|c|c|c|}
\hline & Mean $(S D)$ & Range \\
\hline \multicolumn{3}{|c|}{ Parental dementia stage } \\
\hline & Initial & 15.1 \\
\hline & Moderate & 51.5 \\
\hline & Advanced & 33.4 \\
\hline \multicolumn{3}{|c|}{ Caregiver type } \\
\hline & Primary caregiver & 73.7 \\
\hline & Secondary caregiver & 26.3 \\
\hline \multicolumn{3}{|c|}{ Caregiving time } \\
\hline & More than 5 years & 41.9 \\
\hline & 3 to 4 years & 16.2 \\
\hline & 2 to 3 years & 14.9 \\
\hline & 1 to 2 years & 17.5 \\
\hline & Less than 1 year & 9.5 \\
\hline \multicolumn{3}{|l|}{ Marital status } \\
\hline & Married & 53.9 \\
\hline & Single & 25.4 \\
\hline & Divorced & 13.1 \\
\hline & Separated & 3.5 \\
\hline & Widowed & 4.1 \\
\hline \multicolumn{3}{|c|}{ Level of education } \\
\hline & Elementary school & 0.8 \\
\hline & Middle school & 7.7 \\
\hline & High school & 34.1 \\
\hline & Bachelor's degree & 33.5 \\
\hline & Master's degree or higher & 23.9 \\
\hline \multicolumn{3}{|c|}{ Living arrangement } \\
\hline & Parent with Alzheimer disease & 57.1 \\
\hline & Husband/wife or partner & 52.1 \\
\hline & Son(s) or daughter(s) & 46.4 \\
\hline & Grandson and/or other(s) relative(s) & 15.6 \\
\hline & Alone & 4.7 \\
\hline & Maid or professional caregiver & 4.2 \\
\hline Has siblings & & 89.5 \\
\hline \multicolumn{3}{|c|}{ Position of birth among siblings } \\
\hline & The youngest & 42.2 \\
\hline & The middle one & 30.9 \\
\hline & The oldest & 26.9 \\
\hline \multicolumn{3}{|c|}{ Household monthly income } \\
\hline & $<\$ 856.35$ & 31.8 \\
\hline & $\$ 856.35$ to $\$ 2.569$ & 42.7 \\
\hline & $\$ 2.569$ to $\$ 4.282$ & 11.2 \\
\hline & More than $\$ 4.282$ & 6.2 \\
\hline & Did not respond & 8.1 \\
\hline \multicolumn{3}{|c|}{ Region of Brazil } \\
\hline & North & 5,7 \\
\hline & North-East & 19,1 \\
\hline & Central-West & 7,5 \\
\hline & South & 10,8 \\
\hline & South-East & 56,8 \\
\hline
\end{tabular}

CES-D = Center for Epidemiological Studies-Depression measure, Brazilian Portuguese language version.

The Brazilian Portuguese version of the Familism Scale

The experts assessed the structure and adequacy of expressions contained in the items. Of the 14 translated items, the translation process produced incongruous wording in 9 items: semantic (4 items), idiomatic (4 items), and both conceptual and idiomatic (1 item) divergences. An example of a semantic translation incongruity would be the replacement of 
the literally translated, "Alguém deveria ajudar economicamente com o sustento de irmãos/irmãs mais jovens," with the phrase, "Deve-se ajudar economicamente no sustento de irmãos/irmãs mais jovens." This later phrasing better reflects wording that would be employed by a native Portuguese speaker. In contrast, an idiomatic incongruity in translation was reflected in the transition from the English, "I would help within my means" to the Portuguese, "Eu gostaria de ajudar com os meus recursos".
This shift in verbiage replaces an English colloquialism with a Portuguese phrase reflecting similar intent. In each case, the goal was to improve the readability and interpretability of the questionnaire. The aforementioned process of resolving incongruous translations resulted in wording that was considered to be satisfactory to both translators (see Table 2 in results). In addition, translated familism measurement items are listed in Table 2 in the results section.

Table 2

Description of the familism scale translation for the Brazilian Portuguese language version

\begin{tabular}{|c|c|c|c|c|}
\hline $\begin{array}{l}\text { Item } \\
\text { Original version } \\
\text { (Sagobal et al., 1987) }\end{array}$ & Translation 1 & Translation 2 & $\begin{array}{l}\text { Final Synthesis } \\
\text { (Brazilian Portuguese } \\
\text { Version) } \\
\end{array}$ & $\begin{array}{l}\text { Equivalence } \\
\text { problems }\end{array}$ \\
\hline $\begin{array}{l}\text { 1. One should make great } \\
\text { sacrifices in order to } \\
\text { guarantee a good education } \\
\text { for his/her children }\end{array}$ & $\begin{array}{l}\text { Deve-se fazer grandes } \\
\text { sacrifícios com o objetivo } \\
\text { de garantir uma boa } \\
\text { educação para seus/suas } \\
\text { filho(a)s }\end{array}$ & $\begin{array}{l}\text { Deve-se fazer grandes } \\
\text { sacrifícios com o objetivo de } \\
\text { garantir uma boa educação } \\
\text { para os seus filhos }\end{array}$ & $\begin{array}{l}\text { Deve-se fazer grandes } \\
\text { sacrifícios com o } \\
\text { objetivo de garantir uma } \\
\text { boa educação para os } \\
\text { filhos }\end{array}$ & $\begin{array}{c}\text { Semantic and } \\
\text { Idiomatic }\end{array}$ \\
\hline $\begin{array}{l}\text { 2. One should help } \\
\text { economically with the } \\
\text { support of younger brothers } \\
\text { and sisters }\end{array}$ & $\begin{array}{l}\text { Alguém deveria ajudar } \\
\text { economicamente com o } \\
\text { sustento de irmãos/irmãs } \\
\text { mais jovens }\end{array}$ & $\begin{array}{l}\text { Deve-se ajudar } \\
\text { economicamente no sustento } \\
\text { de irmã(o)s mais jovens }\end{array}$ & $\begin{array}{l}\text { Deve-se ajudar } \\
\text { economicamente no } \\
\text { sustento de irmãos/irmãs } \\
\text { mais jovens }\end{array}$ & Semantic \\
\hline $\begin{array}{l}\text { 3. I would help within my } \\
\text { means if a relative told me } \\
\text { that she/he is in financial } \\
\text { difficulty }\end{array}$ & $\begin{array}{l}\text { Eu ajudaria com os meus } \\
\text { meios se um parente me } \\
\text { dissesse que ela/ele está em } \\
\text { dificuldades financeiras }\end{array}$ & $\begin{array}{l}\text { Se um parente me disser } \\
\text { que está com dificuldades } \\
\text { financeiras, eu gostaria } \\
\text { de ajuda-lo com os meus } \\
\text { recursos }\end{array}$ & $\begin{array}{l}\text { Se um parente me disser } \\
\text { que está com dificuldades } \\
\text { financeiras, eu gostaria } \\
\text { de ajudar com os meus } \\
\text { recursos }\end{array}$ & Idiomatic \\
\hline $\begin{array}{l}\text { 4. One should have the hope } \\
\text { of living long enough to see } \\
\text { his/her grandchildren grow } \\
\text { up }\end{array}$ & $\begin{array}{l}\text { Deve-se ter a esperança de } \\
\text { viver o tempo suficiente } \\
\text { para ver os seus/suas } \\
\text { neto(a)s crescerem }\end{array}$ & $\begin{array}{l}\text { A pessoa deveria ter a } \\
\text { esperança de viver o bastante } \\
\text { para ver os netos crescerem }\end{array}$ & $\begin{array}{l}\text { Deve-se ter a esperança } \\
\text { de viver o tempo } \\
\text { suficiente para ver os } \\
\text { netos crescerem }\end{array}$ & Semantic \\
\hline $\begin{array}{l}\text { 5. Aging parents should live } \\
\text { with their relatives }\end{array}$ & $\begin{array}{l}\text { Pais idosos deveriam viver } \\
\text { com os parentes }\end{array}$ & $\begin{array}{l}\text { Pais idosos deveriam viver } \\
\text { com os parentes }\end{array}$ & $\begin{array}{l}\text { Pais idosos deveriam } \\
\text { viver com os parentes }\end{array}$ & - \\
\hline $\begin{array}{l}\text { 6. A person should share his/ } \\
\text { her home with uncles, aunts } \\
\text { or first cousins if they are in } \\
\text { need }\end{array}$ & $\begin{array}{l}\text { A pessoa deveria dividir } \\
\text { a casa dela/dele com tios, } \\
\text { tias ou primos de primeiro } \\
\text { grau se eles estivessem em } \\
\text { necessidade }\end{array}$ & $\begin{array}{l}\text { A pessoa deve dividir sua } \\
\text { casa com tio(a)s ou primo(a) } \\
\text { s de primeiro grau caso } \\
\text { estivessem precisando }\end{array}$ & $\begin{array}{l}\text { A pessoa deveria dividir } \\
\text { sua casa com tio(a)s ou } \\
\text { primo(a)s de primeiro } \\
\text { grau caso estivessem } \\
\text { precisando }\end{array}$ & Semantic \\
\hline $\begin{array}{l}\text { 7. When someone has } \\
\text { problems, she/he can count } \\
\text { on help from his/her relatives }\end{array}$ & $\begin{array}{l}\text { Quando alguém está } \\
\text { com problemas. Poderia } \\
\text { contar com a ajuda de seus } \\
\text { parentes }\end{array}$ & $\begin{array}{l}\text { Quando alguém tem } \\
\text { problemas pode contar com } \\
\text { a ajuda dos seus familiares }\end{array}$ & $\begin{array}{l}\text { Quando alguém tem } \\
\text { problemas pode contar } \\
\text { com a ajuda dos seus } \\
\text { familiares }\end{array}$ & Semantic \\
\hline $\begin{array}{l}\text { 8. When one has problems, } \\
\text { one can count on the help of } \\
\text { relatives }\end{array}$ & $\begin{array}{l}\text { Quando eu tenho } \\
\text { problemas, eu posso contar } \\
\text { com a ajuda dos parentes }\end{array}$ & $\begin{array}{l}\text { Quando se tem problemas, } \\
\text { pode contar com a ajuda dos } \\
\text { parentes }\end{array}$ & $\begin{array}{l}\text { Quando se tem } \\
\text { problemas, pode se } \\
\text { contar com a ajuda dos } \\
\text { parentes }\end{array}$ & Idiomatic \\
\hline $\begin{array}{l}\text { 9. One can count on help } \\
\text { from his/her relatives to } \\
\text { solve most problems }\end{array}$ & $\begin{array}{l}\text { Poderia contar com a ajuda } \\
\text { dos meus parentes para } \\
\text { resolver a maioria dos } \\
\text { problemas }\end{array}$ & $\begin{array}{l}\text { Pode-se contar com a } \\
\text { ajuda dos familiares para } \\
\text { solucionar a maioria dos } \\
\text { problemas }\end{array}$ & $\begin{array}{l}\text { Pode-se contar com a } \\
\text { ajuda dos familiares para } \\
\text { solucionar a maioria dos } \\
\text { problemas }\end{array}$ & Idiomatic \\
\hline $\begin{array}{l}\text { 10. Much of what a son or } \\
\text { daughter does should be } \\
\text { done to please the parents }\end{array}$ & $\begin{array}{l}\text { Muito do que um filho ou } \\
\text { filha faz, deveria ser feito } \\
\text { para agradar os pais }\end{array}$ & $\begin{array}{l}\text { Muito do que um filho ou } \\
\text { filha faz, deveria ser feito } \\
\text { para agradar os pais }\end{array}$ & $\begin{array}{l}\text { Muito do que um filho ou } \\
\text { filha faz, deveria ser feito } \\
\text { para agradar os pais }\end{array}$ & - \\
\hline $\begin{array}{l}\text { 11. The family should } \\
\text { consult close relatives } \\
\text { (uncles, aunts) concerning its } \\
\text { important decisions }\end{array}$ & $\begin{array}{l}\text { A família deveria consultar } \\
\text { parentes próximos (tios/ } \\
\text { tias) a respeito das suas } \\
\text { decisões importantes }\end{array}$ & $\begin{array}{l}\text { A família deveria consultar } \\
\text { parentes próximos (tios/tias) } \\
\text { a respeito das suas decisões } \\
\text { importantes }\end{array}$ & $\begin{array}{l}\text { A família deveria } \\
\text { consultar parentes } \\
\text { próximos (tios/tias) } \\
\text { a respeito das suas } \\
\text { decisões importantes }\end{array}$ & - \\
\hline
\end{tabular}


Falcão, D. V. S., Paulson, D., Legon, M. H., \& Irurita-Ballesteros, C. (2019). Familism Scale in a Sample of Caregivers.

...continuation

\begin{tabular}{|c|c|c|c|c|}
\hline $\begin{array}{l}\text { Item } \\
\text { Original version } \\
\text { (Sagobal et al., 1987) } \\
\end{array}$ & Translation 1 & Translation 2 & $\begin{array}{l}\text { Final Synthesis } \\
\text { (Brazilian Portuguese } \\
\text { Version) }\end{array}$ & $\begin{array}{c}\text { Equivalence } \\
\text { problems }\end{array}$ \\
\hline $\begin{array}{l}\text { 12. One should be } \\
\text { embarrassed about the } \\
\text { bad things done by his/her } \\
\text { brothers or sisters }\end{array}$ & $\begin{array}{l}\text { Deve-se sentir vergonha } \\
\text { das coisas más feitas pelos } \\
\text { irmãos ou irmãs }\end{array}$ & $\begin{array}{l}\text { Eu deveria sentir vergonha } \\
\text { pelas coisas ruins feitas pelos } \\
\text { meus irmãos ou irmãs. }\end{array}$ & $\begin{array}{l}\text { Deve-se sentir vergonha } \\
\text { das coisas más feitas } \\
\text { pelos irmãos ou irmãs }\end{array}$ & Idiomatic \\
\hline $\begin{array}{l}\text { 13. Children should live in } \\
\text { their parents' house until } \\
\text { they get married? }\end{array}$ & $\begin{array}{l}\text { Os filhos deveriam viver } \\
\text { na casa dos pais até se } \\
\text { casarem? }\end{array}$ & $\begin{array}{l}\text { Os filhos deveriam viver na } \\
\text { casa dos pais até se casarem? }\end{array}$ & $\begin{array}{l}\text { Os filhos deveriam viver } \\
\text { na casa dos pais até se } \\
\text { casarem? }\end{array}$ & - \\
\hline $\begin{array}{l}\text { 14. One of the most } \\
\text { important goals in life is to } \\
\text { have children }\end{array}$ & $\begin{array}{l}\text { Um dos objetivos mais } \\
\text { importantes na vida é ter } \\
\text { filhos }\end{array}$ & $\begin{array}{l}\text { Um dos objetivos mais } \\
\text { importantes na vida é ter } \\
\text { filhos }\end{array}$ & $\begin{array}{l}\text { Um dos objetivos mais } \\
\text { importantes na vida é ter } \\
\text { filhos }\end{array}$ & - \\
\hline
\end{tabular}

\section{Confirmatory Factor Analysis}

A confirmatory factor analysis was employed to examine whether a 3-factor structure is supported. The 14 items of the original Familism Scale loaded on factors representing familial obligation, support from the family, and family as referents, respectively. Factor loadings for these three factors modeled are shown in Table 3 . The results do not fully support the 3-factor structure with all 14 items of the original scale $(\mathrm{RMSEA}=.062 ; \mathrm{CFI}=.889 ; \mathrm{SRMR}=.051 ; \chi 2=279.3 ; d f=$ $.74 ; p<.001)$. All factor loadings (lambdas) were statistically significant, $(p<.05)$, with values varying between 0.37 (Item 1. One should make great sacrifices in order to guarantee a good education for his/her children) and 0.84 (Item 8 . When one has problems, one can count on the help of relatives).

\section{Scale Modification}

Two models were tested to determine the best fitting model. Modification of the examined model was completed by excluding first item 1, and then both items 1 and 11 . These decisions and corresponding statistics were reached based on the following theoretical and empirical considerations. Analysis of familism scale items suggests conceptual discontinuity between items associated with the first factor in the study of caregiving dynamics. Item 1 addresses perception of obligation in the context of education of the children. While it may be that this item relates to the construction of caregiving more broadly, it may also be that the content of the question is not directly applicable to the context of dementia caregiving. Of these six items, Item 1 also had the weakest factor loading. In combination, this suggests that the scale may be improved by the removal of item 1 .

The resulting model, model 2 , was also subjected to confirmatory factor analysis. Fit indices for Model 2, which omitted just item 1, were essentially unchanged from the prior model $(\mathrm{RMSEA}=.063 ; \mathrm{CFI}=.899$; $\mathrm{SRMR}=.049$; $\chi 2=237.78 ; d f=.62 ; p<.001)$. One additional exploratory revision was tested. The second revision to the measure, the removal of item 11, reflects the distinction between nuclear family and extended family as referents. It may be that survey respondents draw distinctions between immediate and secondary family members. These items were selected for exclusion on the basis of their relatively low factor loadings and the low percentages of item-level data accounted for by the hypothesized latent constructs $\left(\lambda=.37, p<.001, \mathrm{r}^{2}=.14\right.$ and $\lambda=.39, p<.001, \mathrm{r}^{2}=.15$, respectively). In contrast, fit indices for Model 3 suggested that the proposed three-factor model fits the remaining 12-items well (RMSEA $=.063$, $\mathrm{CFI}=.912 ; \mathrm{SRMR}=.048 ; \chi 2=194.88 ; d f=.51 ; p<.001)$ based on established model fit guidelines (Hooper et al., 2008; Hu \& Bentler, 1999).

Table 3

Results of the confirmatory factor analysis

\begin{tabular}{|c|c|c|c|c|c|c|c|}
\hline \multirow[b]{2}{*}{ RMSEA } & \multirow[b]{4}{*}{ Item No. } & \multicolumn{2}{|c|}{ Model 1 (Full) } & \multicolumn{2}{|c|}{ Model 2} & \multicolumn{2}{|c|}{ Model 3} \\
\hline & & \multicolumn{2}{|c|}{0.062} & \multicolumn{2}{|c|}{0.063} & \multicolumn{2}{|c|}{0.063} \\
\hline \multirow[t]{2}{*}{ CFI } & & \multicolumn{2}{|c|}{0.889} & \multicolumn{2}{|c|}{0.899} & \multicolumn{2}{|c|}{0.912} \\
\hline & & $\lambda$ & $\mathrm{r} 2$ & $\lambda$ & $\mathrm{r} 2$ & $\lambda$ & $\mathrm{r} 2$ \\
\hline \multirow[t]{6}{*}{ Factor 1} & 1 & 0.37 & 0.14 & & & & \\
\hline & 2 & 0.53 & 0.28 & 0.52 & 0.27 & 0.52 & 0.27 \\
\hline & 3 & 0.61 & 0.37 & 0.62 & 0.39 & 0.63 & 0.40 \\
\hline & 4 & 0.45 & 0.20 & 0.43 & 0.19 & 0.44 & 0.19 \\
\hline & 5 & 0.43 & 0.19 & 0.42 & 0.18 & 0.42 & 0.18 \\
\hline & 6 & 0.58 & 0.33 & 0.58 & 0.34 & 0.58 & 0.34 \\
\hline Factor 2 & 7 & 0.80 & 0.64 & 0.80 & 0.64 & 0.80 & 0.64 \\
\hline
\end{tabular}


...continuation

\begin{tabular}{|c|c|c|c|c|c|c|c|}
\hline \multirow{4}{*}{$\begin{array}{c}\text { RMSEA } \\
\text { CFI }\end{array}$} & \multirow[b]{4}{*}{ Item No. } & \multicolumn{2}{|c|}{ Model 1 (Full) } & \multicolumn{2}{|c|}{ Model 2} & \multicolumn{2}{|c|}{ Model 3} \\
\hline & & \multicolumn{2}{|c|}{0.062} & \multicolumn{2}{|c|}{0.063} & \multicolumn{2}{|c|}{0.063} \\
\hline & & \multicolumn{2}{|c|}{0.889} & \multicolumn{2}{|c|}{0.899} & \multicolumn{2}{|c|}{0.912} \\
\hline & & $\lambda$ & $\mathrm{r} 2$ & $\lambda$ & $\mathrm{r} 2$ & $\lambda$ & $\mathrm{r} 2$ \\
\hline \multirow{7}{*}{ Factor 3} & 8 & 0.84 & 0.71 & 0.84 & 0.71 & 0.84 & 0.71 \\
\hline & 9 & 0.65 & 0.42 & 0.65 & 0.42 & 0.64 & 0.41 \\
\hline & 10 & 0.64 & 0.40 & 0.64 & 0.41 & 0.61 & 0.37 \\
\hline & 11 & 0.39 & 0.15 & 0.39 & 0.15 & & \\
\hline & 12 & 0.46 & 0.21 & 0.46 & 0.21 & 0.44 & 0.19 \\
\hline & 13 & 0.60 & 0.36 & 0.59 & 0.35 & 0.63 & 0.40 \\
\hline & 14 & 0.55 & 0.30 & 0.55 & 0.30 & 0.59 & 0.35 \\
\hline
\end{tabular}

Note. $\lambda=$ factor loading; $\mathrm{r}^{2}=$ Variance accounted for by model. Factor $1=$ familial obligations; Factor 2 = perceived support from the family; Factor 3 = family as referents.

\section{Reliability and Validity}

The Brazilian Portuguese versions of the Familism Scale (14-item) had an internal consistency (Cronbach's alpha) of .80. Cronbach's alpha for factors 1,2 and 3 was .66, .79 and .65 , respectively. The thirteen-item version had Cronbach's of .78 (factor $1=.64, .79$ and .65 , respectively) and the twelveitem version had Cronbach's of .79 (factor $1=.64, .79$ and .65 , respectively). In addition, bivariate correlation analysis was conducted on the data including the Filial Obligation, CES-D and
Life Satisfaction scales. In the case of the Familism scale, overall scores as well as separate scores for the three factors in this scale were included. Convergent and divergent validity are suggested by variable correlations between scores on the familism measure and other constructs with varying conceptual overlap. Scores on the 14-item Familism measure had weak correlation with filial obligation $(r=.248)$ and even weaker correlation with reported life satisfaction $(r=.160)$. Familism had a small negative correlation with depressive symptomatology $(r=-.043$; see Table 4$)$.

Table 4

Pearson's correlation between indices of the familism measure and other key variables

\begin{tabular}{|c|c|c|c|c|c|c|c|}
\hline & Familism-14 & Familism-12 & Factor 1 & Factor 2 & Factor 3 & $\begin{array}{l}\text { Filial } \\
\text { obligation }\end{array}$ & $\begin{array}{l}\text { Life } \\
\text { satisfaction }\end{array}$ \\
\hline Familism-14 & - & & & & & & \\
\hline Familism-12 & $0.99 * *$ & - & & & & & \\
\hline Factor 1 & $0.82 * *$ & $0.83 * *$ & - & & & & \\
\hline Factor 2 & $0.70 * *$ & $0.72 * *$ & $0.47 * *$ & - & & & \\
\hline Factor 3 & $0.77 * *$ & $0.77 * *$ & $0.43 * *$ & $0.29 * *$ & - & & \\
\hline Filial obligation & $0.25 * *$ & $0.24 * *$ & $0.25^{* *}$ & $0.11 * *$ & $0.18 * *$ & - & \\
\hline Life satisfaction & $0.16^{* *}$ & $0.16^{* *}$ & $0.10^{* *}$ & $0.22 * *$ & 0.06 & 0.02 & - \\
\hline CES-D & -0.04 & -0.05 & -0.02 & -0.16 & 0.03 & 0.01 & -0.61 \\
\hline
\end{tabular}

Note. ${ }^{* *} \mathrm{p}<.01$; Factor 1 = familial obligations; Factor 2 = perceived support from the family; Factor $3=$ family as referents. CES-D = Center for Epidemiological Studies Depression Measure.

\section{Discussion}

The results of this study suggest that the Brazilian Portuguese version of the Familism scale has adequate psychometric properties, and it constitutes a useful instrument to assess familism among Brazilian Alzheimer's disease caregivers. Future research examining the factor structure and relation with other variables of interest is needed. A threefactor model shows acceptable overall fit and good reliability indices, which supports past findings that familism can be characterized as having three non-orthogonal dimensions representing family obligation, perceived family support, and family as a reference. Internal consistency for the Brazilian Portuguese Familism Scale was similar to the original FS. However, the 12-item alternate model was associated with better fit indices. As anticipated, scores on the translated familism measure were significantly correlated with scores on a measure of filial obligation, and more moderately with measures of life satisfaction and depression. Measures of life satisfaction and depressive symptomatology were selected as variables that are impacted by dementia caregiving, and are quantitatively related to familism, but should be measurably distinct from familism. Thus, the low correlations between the overall familism score and the three dimensions scores with 
Falcão, D. V. S., Paulson, D., Legon, M. H., \& Irurita-Ballesteros, C. (2019). Familism Scale in a Sample of Caregivers.

scores on life satisfaction and depressive symptom measures support the divergent validity of this familism measure. These findings support the convergent and discriminant validity of this translated familism measure. The relationships between them were in line with the relationships already established in the literature, though somewhat attenuated in other studies (Losada et al., 2008). Future research may employ this measure to refine a more articulated model of interrelationships between these variables.

Adaptation of this preliminary measure of familism among Brazilian dementia caregivers included removal of two items. Model revisions of this nature are fraught with methodological dangers and should be conducted paying attention to theoretical implications and replication of findings. Thus, it is critical that future research seek to replicate these findings. Also, it was necessary the removal of Item 1, which references the care of children and employs the English word, "sacrifice". The original scale was developed to study how national diversity between Spanish speaking peoples and acculturation to the United States influence the experience of familism, and there was no immediate context of dementia caregiving. It may be that Item 1 contributed comparably less to the family obligation dimension because it was explicitly incongruent with the context of dementia caregiving research. It may also be that this question better reflects the individualistic cultural norms found in the United States. Regardless, our findings suggest that the translated questionnaire may be improved by the removal of this item. With respect to item 11, this question references the extended family. The sample was largely drawn from the more urban Southeast region of Brazil. It may be that predominantly urban respondents focus less on the extended family as social references and instead place more emphasis on immediate family members as referents. Alternatively, it may be that dementia caregivers are more isolated and focus their attention disproportionately on the immediate family members for whom they provide care. One limitation of the analytic strategy employed in this study is the inability to directly contrast the overall fit of competing models. The difference between fit indices generated by the three models described herein are, in fact, rather small. Nonetheless, the third model based on twelve questionnaire items appears to fit well based on a priori cutoffs. As noted above, posthoc model revisions such as these may be made based on theoretical considerations with the goal of improving model fit. Such model revisions should be interpreted cautiously and require thoughtful replication prior to widespread use.

World cultures vary widely in how care for aging parents is socially constructed. Though this study focuses on a single nation, it is very likely that considerable variability exists in this regard given the considerable cultural diversity across Brazil. Brazilian families are not homogeneous. Many are multi-household, multigenerational, and/or multilingual, whereas others are not. Additionally, differences inevitably exist between the shared understanding of role obligations within a family unit and one's perception of how best to serve the interests of their own kin. According to Wallace and Facio
(1987), familism as conceptualized in the literature does not allow for these kinds of differences. For example, familism is understood as a shared responsibility between everyone in the family. Past research found that among Brazilian daughter caregivers of parents with $\mathrm{AD}$, perceptions of obligation by gratitude were especially compelling motivations (Falcão, Teodoro, \& Bucher-Maluschke, 2016). Cross-cultural research is necessary if we are to fully appreciate how the cultural diversity of Brazil informs caregivers' perceptions of familism. This study, in combination with other work, may contribute to this goal.

Not unlike the challenge of studying familism across Latin America, the study of familism among Asian-American families is complicated by a two-fold methodological challenge. There are over 20 Asian-American subgroups with distinct languages, histories, religious affiliations, and other cultural markers, and the paucity of culture-specific constructs leaves critical aspects of familism unmeasured; familism measures developed with other populations are not likely to capture attitudes and behaviors unique to Asian-Americans in the aggregate, as well as to particular subgroups of Asian Americans. Dynamic pathways of acculturation are interwoven into Asian-American family processes in subgroup-specific ways that may not be captured by conventional measures (Choi, Kim, Pekelnicky, \& Kim, 2013). For instance, past research (Jin \& Kim, 2015) found that the Korean married adult offspring caregivers turn out to have a higher sense of "familism as a source of support", while Chinese ones have a higher sense of "obligation as a family member".

There exist numerous and contradictory results concerning familism values in the caregiving literature. Familism has been described as a source of relative advantage in that high levels of familism may partially mitigate adversity conferred by caregiver burden and facilitate perception of positive experiences in caregiving (Koerner \& Shirai, 2012). Losada et al. (2010) reported that among Spanish caregivers, dysfunctional thoughts were positively associated with all three of the familism factors modeled in this study. Other studies related to Latino Alzheimer's caregivers (Gelman, 2014) found that beliefs about familism and its influence on elder caregiving were not consistent across caregivers' personal narratives. Some caregivers viewed familism as a way of facilitating traditional caregiving; however, other caregivers rejected familism as irrelevant to their own caregiving experiences or felt conflicted between familistic principles and their own negative feelings about caregiving. In combination with other studies, the results of this study may be able to resolve some of these apparent incongruities and advance research on familism in general and dementia caregiving specifically.

Despite further advancing the study of familism in life in Brazilian culture, this study has some limitations. First, this paper examined the translated familism measure in a convenience sample of Brazilian dementia caregivers. It may be that this sampling methodology results in the systematic under-recruitment of dementia caregivers with clinicallyrelevant distress and impairment resulting from their roles 
as caregivers. Conversely, it may be that more distressed caregivers seek out information such as that offered as compensation for this study. Thus, it is very likely that this convenience sample is biased in this regard. An additional way in which use of a convenience sample may influence interpretability of these results is that this sample was welleducated, and fairly wealthy by contrast with population statistics in Brazil. Respondents to this online survey were also evidently literate and had internet access. Additional studies are necessary to examine the applicability of FS in other social contexts. Future research may address these limitations by recruiting representative samples of dementia caregivers from healthcare institutions serving these families. Secondly, this study relied on self-report measures for adult children caregivers, and may not reflect familism among other dementia caregivers including spouses, extended family, and family friends. This study also focuses on dementia caregiving to the exclusion of other types of caregiving, such as caregiving for individuals with traumatic brain injuries or developmental delays. In the future, this measure may be used with and evaluated in other contexts.

Additionally, select variables were identified to demonstrate the convergent and divergent validity of this familism measure, though familism is a complex construct that is believed to broadly relate to social variables. Thus, true validity of this translated measure with Brazilian caregivers is suggested to be ultimately demonstrated by the emergence of a nomological network (Cronbach \& Meehl, 1955). Finally, legitimate cross-cultural research may be facilitated by the adaptation and validation of the Familism scale to other languages and different countries are recommended.

In conclusion, the present findings support the Familism scale as a valid and reliable measurement tool of the cultural construction. Overall, this study suggests that the Familism Scale (Brazilian-Portuguese version) has acceptable psychometric properties. Researchers may rely on this version of the scale to measure a strong identification and fixation between individuals and their families; and a strong feeling of loyalty, reciprocity and solidarity among the members of the same family in Brazilian samples.

\section{References}

Arévalo-Flechas, L. C., Acton, G., Escamilla, M., Bonner, P., \& Lewis, S. L. (2014). Latino Alzheimer's caregivers: What is important to them? Journal of Managerial Psychology, 29(6), 661-684. doi:10.1108/JMP-11-2012-0357

Bardis, P. D. (1959). A familism scale. Marriage \& Family Living, 21(4), 340-341. doi:10.2307/347107

Borsa, J. C., Damásio, B. F., \& Bandeira, D. R. (2012). Adaptação e validação de instrumentos psicológicos entre culturas: Algumas considerações [Cross-cultural adaptation and validation of psychological instruments: Some considerations]. Paidéia (Ribeirão Preto), 22(53), 423-432. doi:10.1590/S0103-863X2012000300014
Bostean, G., \& Gillespie, B. J. (2018). Acculturation, acculturative stressors, and family relationships among Latina/o immigrants. Cultural Diversity \& Ethnic Minority Psychology, 24(1), 126-138. doi:10.1037/cdp0000169

Campos, B., Ullman, J. B., Aguilera, A., \& Schetter, C. D. (2014). Familism and psychological health: The intervening role of closeness and social support. Cultural Diversity \& Ethnic Minor Psychology, 20(2), 191-201. doi:10.1037/a0034094

Casado, B. L., Lee, S. E., Hong, M., \& Hong, S. (2015). The experience of family caregivers of older Korean americans with dementia symptoms. Clinical Gerontologist, 38(1), 32-48. doi:10.1080/07317115.2014.970316

Choi, Y., Kim, Y. S., Pekelnicky, D. D., \& Kim, H. J. (2013). Preservation and modification of culture in family socialization: Development of parenting measures for Korean immigrant families. Asian American Journal of Psychology, 4(2), 143-154. doi:10.1037/a0028772

Cicirelli, V. G. (1992). Family caregiving: Autonomous and paternalistic decision making. Thousand Oaks, CA: Sage.

Corona, K., Campos, B., \& Chen, C. (2017). Familism is associated with psychological well-being and physical health: Main effects and stress-buffering effects. Hispanic Journal of Behavioral Sciences, 39(1), 46-65. doi:10.1177/0739986316671297

Cronbach, L. J., \& Meehl, P. E. (1955). Construct validity in psychologicaltests. PsychologicalBulletin, 52(4),281-302. doi: $10.1037 / \mathrm{h} 0040957$

Diener, E., Emmons, R. A., Larsen, R. J., \& Griffin, S. (1985). The satisfaction with life scale. Journal of Personality Assessment, 49(1), 71-75. doi:10.1207/ s15327752jpa4901_13

Falcão, D. V. S., Teodoro, M. L. M., \& Bucher-Maluschke, J. S. N. F. (2016). Family cohesion: A study on caregiving daughters of parents with Alzheimer's disease. Interpersona, 10(Suppl. 1), 61-74. doi:10.5964/ijpr.v10isupp1.244

Fuller-Iglesias, H. R., \& Antonucci, T. C. (2016). Familism, social network characteristics, and well-being among older adults in Mexico. Journal of Cross-Cultural Gerontology, 31(1), 1-17. doi:10.1007/s10823-015-9278-5

Gelman, C. R. (2014). Familismo and its impact on the family caregiving of Latinos with Alzheimer's disease: A complex narrative. Research on Aging, 36(1), 40-71. doi: $10.1177 / 0164027512469213$

Gouveia, V. V., Milfont, T. L., Fonseca, P. N., \& Coelho, J. A. P. M. (2009). Life satisfaction in Brazil: Testing the psychometric properties of the satisfaction with life scale (SWLS) in five Brazilian samples. Social Indicators Research, 90, 267. doi:10.1007/s11205-008-9257-0 
Falcão, D. V. S., Paulson, D., Legon, M. H., \& Irurita-Ballesteros, C. (2019). Familism Scale in a Sample of Caregivers.

Halgunseth, L. C., Espinosa-Hernández, G., Joeng, H.-K., Chang, Y., Card, N., \& Reid, A. (2017). Parenting and adolescent adjustment in Mexico: Initial evidence of validity for the Mexican Parenting Questionnaire for Adolescents (MPQ-A). Journal of Child and Family Studies, 26(2), 471-481. doi:10.1007/s10826-016-0581-8

Hernández, M. M., \& Bámaca-Colbert, M. Y. (2016). A behavioral process model of familism. Journal of Family Theory \& Review, 8(4), 463-483. doi:10.1111/jftr.12166

Hooper, D., Coughlan, J., \& Mullen, M. (2008). Structural equation modelling: Guidelines for determining model fit. Electronic Journal of Business Research Methods, 6(1), 53-60. Retrieved from: https://arrow.dit.ie/cgi/ viewcontent.cgi?referer=https://scholar.google.com. $\mathrm{br} / \&$ httpsredir $=1 \&$ article $=1001 \&$ context $=$ buschmanart

Hu, L., \& Bentler, P. M. (1999). Cutoff criteria for fit indexes in covariance structure analysis: Conventional criteria versus new alternatives. Structural Equation Modeling, 6(1), 1-55. doi:10.1080/10705519909540118

International Test Commission. (2010). International Test Commission guidelines for translating and adapting tests: Version 2010. Retrieved from http://www. psyktestbarn.no/cms/ptb_mm.nsf/lupgraphics/ITC $\% 20$ guidelines.pdf/\$file/ITC\%20guidelines.pdf

Jin, H., \& Kim, Y. J. (2015). Familism and Caregiving Stress of Adult Married Children: Focused on comparison between Korean and Chinese. International Information Institute (Tokyo). Information, 18(5B), 2169

Kaplan, D. (2008). Structural equation modeling: Vol. 10. Foundations and extensions. Thousand Oaks, CA: Sage.

Keeler,A. R., Siegel, J. T., \& Alvaro, E. M. (2014). Depression and help seeking among Mexican-Americans: The mediating role of familism. Journal of Immigrant and Minority Health, 16(6), 1225-1231. doi:10.1007/s10903013-9824-6

Killoren, S. E., Alfaro, E. C., \& Kline, G. (2016). Mexican American emerging adults' relationships with siblings and dimensions of familism values. Personal Relationships, 23(2), 234-248. doi:10.1111/pere.12125

Koerner, S. S., \& Shirai, Y. (2012). The negative impact of global perceptions of and daily care-related family conflict on Hispanic caregivers: Familism as a potential moderator. Aging \& Mental Health, 16(4), 486-499. doi: 10.1080/13607863.2011.638905

Lee, H. J., \& Szinovacz, M. E. (2016). Positive, negative, and ambivalent interactions with family and friends: Associations with well-being. Journal of Marriage and Family, 78(3), 660-679. doi:10.1111/jomf.12302

Li, C.-H. (2016). Confirmatory factor analysis with ordinal data: Comparing robust maximum likelihood and diagonally weighted least squares. Behavior Research Methods, 48(3), 936-949. doi:10.3758/s13428-015-0619-7
Lima-Costa, M. F., Peixoto, S. V., Malta, D. C., Szwarcwald, C. L., \& Mambrini, J. V. M. (2017). Informal and paid care for Brazilian older adults (National Health Survey, 2013). Revista de Saúde Pública, 51(Suppl. 1), 6s. doi:10.1590/S1518-8787.2017051000013

Losada, A., Knight, B. G., Márquez-González, M., Montorio, I., Etxeberría, I., \& Peñacoba, C. (2008). Confirmatory factor analysis of the familism scale in a sample of dementia caregivers. Aging \& Mental Health, 12(4), 504508. doi:10.1080/13607860802224227

Losada, A., Márquez-González, M., Knight, B. G., Yanguas, J., Sayegh, P., \& Romero-Moreno, R. (2010). Psychosocial factors and caregivers' distress: Effects of familism and dysfunctional thoughts. Aging \& Mental Health, 14(2), 193-202. doi:10.1080/13607860903167838

Marsiglia, F. F., Booth, J. M., Baldwin, A., \& Ayers, S. (2013). Acculturation and life satisfaction among immigrant Mexican adults. Advances in Social Work, 14(1), 4964. Retrieved from http://journals.iupui.edu/index.php/ advancesinsocialwork/article/view/3758/13461

McCleary, L., \& Blain, J. (2013). Cultural values and family caregiving for persons with dementia. Indian Journal of Gerontology, 27(1), 178-201. Retrieved from https://www. researchgate.net/publication/255754376_Cultural_values_ and_family_caregiving_for_persons_with_dementia

Mendez-Luck, C.A.,Applewhite, S. R., Lara, V.E., \& Toyokawa, N. (2016). The concept of familism in the lived experiences of Mexican-origin caregivers. Journal of Marriage and Family, 78(3), 813-829. doi:10.1111/jomf.12300

Miyawaki, C. E. (2016). Caregiving practice patterns of Asian, Hispanic, and non-Hispanic white American family caregivers of older adults across generations. Journal of Cross-Cultural Gerontology, 31(1), 35-55. doi:10.1007/s10823-016-9281-5

Moreno, J. A., Nicholls, E., Ojeda, N., De los Reyes-Aragón, C. J., Rivera, D., \& Arango-Lasprilla, J. C. (2015). Caregiving in dementia and its impact on psychological functioning and health-related quality of life: Findings from a Colombian sample. Journal of Cross-Cultural Gerontology, 30(4), 393408. doi:10.1007/s10823-015-9270-0

Muthén, L. K., \& Muthén, B. O. (2012). Mplus Version 7 user's guide. Los Angeles, CA: Muthén \& Muthén.

Ojeda, L., \& Piña-Watson, B. (2013). Day laborers' life satisfaction: The role of familismo, spirituality, work, health, and discrimination. Cultural Diversity and Ethnic Minority Psychology, 19(3), 270-278. doi:10.1037/a0032961

Perez, G. K., \& Cruess, D. (2014). The impact of familism on physical and mental health among Hispanics in the United States. Health Psychology Review, 8(1), 95-127. doi:10.1080/17437199.2011.569936 
Pinquart, M., Sörensen, S., \& Song, Y. (2018). Older persons' care-related preferences: Cultural and cross-cultural influences. In T. Boll, D. Ferring, \& J. Valsiner (Eds.), Cultures of care in aging (pp. 123-147). Charlotte, NC: Information Age.

Qualtrics. (2013). Qualtrics Research Suite: Version 2013. Provo, UT: Author. Retrieved from: https://www. qualtrics.com

Radloff, L. S. (1977). The CES-D scale: A self-report depression scale for research in the general population. Applied Psychological Measurement, 1(3), 385-401. doi:10.1177/014662167700100306

Sabogal, F., Marín, G., Otero-Sabogal, R., Marín, B. V., \& Perez-Stable, E. J. (1987). Hispanic familism and acculturation: What changes and what doesn't? Hispanic Journal of Behavioral Sciences, 9(4), 397-412. doi:10.1177/07399863870094003

Santos, R. L., de Sousa, M. F., Ganem, A. C., Silva, T. V., \& Dourado, M. C. N. (2013). Cultural aspects in dementia: Differences in the awareness of Brazilian caregivers. Trends in Psychiatry and Psychotherapy, 35(3), 191-197. doi:10.1590/S2237-60892013000300006

Song, Y., Yan, E. C. W., \& Sörensen, S. (2017). The effects of familism on intended care arrangements in the process of preparing for future care among one-child parents in urban China. Ageing \& Society, 37(7), 1416-1434. doi:10.1017/S0144686X16000349

Stein, G. L., Cupito, A. M., Mendez, J. L., Prandoni, J., Huq, N., \& Westerberg, D. (2014). Familism through a developmental lens. Journal of Latina/o Psychology, 2(4), 224-250. doi:10.1037/lat0000025

Stuifbergen, M. C., \& Van Delden, J. J. (2011). Filial obligations to elderly parents: A duty to care? Medicine, Health Care and Philosophy, 14(1), 63-71. doi:10.1007/s11019-010-9290-z

Tabachnick, B. G., \& Fidell, L. S. (2013). Using multivariate statistics (6th ed.). Boston, MA: Allyn \& Bacon.

Triandis, H. C., Marín, G., Betancourt, H., Lisansky, J., \& Chang, B.-H. (1982). Dimensions of familism among Hispanic and mainstream Navy recruits. In H. C. Triandis (Ed.), Personnel technology: An examination of Hispanic and general population perceptions of organizational environments (pp. 1-12). Champaign, IL: University of Illinois. Retrieved from https:/apps.dtic.mil/dtic/tr/ fulltext/u2/a114898.pdf

Valdivieso-Mora, E., Peet, C. L., Garnier-Villarreal, M., Salazar-Villanea, M., \& Johnson, D. K. (2016). A systematic review of the relationship between familism and mental health outcomes in Latino population. Frontiers in Psychology, 7, 1632. doi:10.3389/fpsyg.2016.01632
Vellone, E., Piras, G., Venturini, G., Alvaro, R., \& Cohen, M. Z. (2012). The experience of quality of life for caregivers of people with Alzheimer's disease living in Sardinia, Italy. Journal of Transcultural Nursing, 23(1), 46-55. doi:10.1177/1043659611414199

Villalobos, B. T., \& Bridges, A. J. (2015). Testing an attribution model of caregiving in a latino sample: The roles of familismo and the caregiver-care recipient relationship. Journal of Transcultural Nursing, 27(4), 322-332. doi:10.1177/1043659615590476

Wallace, S. P., \& Facio, E. L. (1987). Moving beyond familism: Potential contributions of gerontological theory to studies of Chicano/Latino aging. Journal of Aging Studies, 1(4), 337-354. doi:10.1016/0890-4065(87)90009-0

Deusivania Vieira da Silva Falcão is a Professor of the Universidade de São Paulo, São Paulo-SP, Brazil. Postdoctoral Researcher of the University of Central Florida, Orlando-Florida, USA.

Daniel Paulson is a Professor of Department of Psychology of the University of Central Florida, Orlando-Florida, USA.

Manuel Herrera Legon is a Ph.D candidate of Department of Psychology of the University of Central Florida, Orlando-Florida, USA.

Carolina Irurita-Ballesteros is a Postdoctoral Researcher of Department of Psychology of the University of Central Florida, Orlando-Flórida, USA.

\section{Authors' Contribution:}

All authors made substantial contributions to the conception and design of this study, to data analysis and interpretation, and to the manuscript revision and approval of the final version. All the authors assume public responsability for content of the manuscript.

Received: Jan. 15, 2018

1st Revision: Jun. 22, 2018

2nd Revision: Sep. 11, 2018

Approved: Nov. 07, 2018

How to cite this article:

Falcão, D. V. S., Paulson, D., Legon, M. H., \& Irurita-Ballesteros, C. (2019). Familism scale: Confirmatory factor analysis in a sample of caregivers of older adults. Paidéia (Ribeirão Preto), 29, e2936. doi: http://dx.doi.org/10.1590/1982-4327e2936 